\title{
Carcinoid tumour of the oesophagus: a systematic review
}

\author{
Mazaher Ramezani ${ }^{1}$, Masoud Sadeghi ${ }^{2,3}$ \\ ${ }^{1}$ Molecular Pathology Research Centre, Emam Reza Hospital, Kermanshah University of Medical Sciences, Kermanshah, Iran \\ ${ }^{2}$ Medical Biology Research Centre, Kermanshah University of Medical Sciences, Kermanshah, Iran \\ ${ }^{3}$ Students Research Committee, Kermanshah University of Medical Sciences, Kermanshah, Iran
}

Gastroenterology Rev 2018; 13 (3): 196-199

DOI: https://doi.org/10.5114/pg.2018.78285

Key words: neuroendocrine tumour, carcinoid tumour, oesophagus.

Address for correspondence: Masoud Sadeghi MSc, Medical Biology Research Centre, Kermanshah University of Medical Sciences, 67145-1673 Kermanshah, Iran, phone: +98 9188566877, e-mail: sadeghi_mbrc@yahoo.com

\begin{abstract}
Introduction: Knowledge about oesophageal carcinoids is based primarily on case reports, and therefore information about them is incomplete.

Aim: To collect information on oesophageal carcinoid tumours in a systematic review study.

Material and methods: Databases including PubMed, Scopus, and Web of Science were searched for the characteristics of oesophageal carcinoid tumour. Studies included original articles, case series, or case reports, reporting at least one of the characteristics of benign carcinoid tumour or carcinoid tumour.

Results: Out of 670 studies searched, after evaluation and excluding non-relevant studies, 14 studies were included and analysed in the systematic review. These studies included 19 patients with carcinoid tumour of whom $57.9 \%$ were males with a mean age of 55.5 years. Dysphagia and weight loss were the most prevalent symptoms and signs in the patients. Lower oesophagus was the most prevalent site of tumour.

Conclusions: This meta-analysis showed that the mean age at diagnosis of oesophageal carcinoid was around 55 years, with 1.4 times greater prevalence among males, and located mainly in the distal oesophagus. The mean tumour size was $2.4 \mathrm{~cm}$. The main symptoms and signs of this disease were dysphagia, weight loss, and reflux. The tumour behaviour was mainly non-aggressive except for cases associated with adenocarcinoma.
\end{abstract}

\section{Introduction}

Endocrine tumours of the gastrointestinal tract, which are known as carcinoids, herein collectively termed neuroendocrine tumours (NETs), originate from the diffuse neuroendocrine cell system [1]. Typical carcinoid, atypical carcinoid, small cell neuroendocrine carcinoma, and large cell neuroendocrine carcinoma are subgroups of neuroendocrine tumours [2]. The traditional term of carcinoid is not adequate to cover all NETs [3]. Over $90 \%$ of all carcinoid tumours originate in the gastrointestinal tract, and most carcinoid tumours are gastrointestinal in origin, but they only account for $1.5 \%$ of all gastrointestinal neoplasms [4]. Neuroendocrine tumours of the oesophagus are very rare and represent only $0.05 \%$ of all gastrointestinal NETs [5] and therefore are one of the rarest of all carcinoid tumours [6]. Brenner et al. were the first researchers to describe a carci- noid originating within the oesophagus [7]. Diagnosis of oesophageal carcinoid can be suggested by barium meal, endoscopy with biopsy, and computed tomography scanning [3]. Nowadays, somatostatin analogues play a fundamental role in the treatment of NETs of the gastrointestinal tract [8]. Because knowledge about oesophageal carcinoid is based primarily on case reports, the treatment of choice has not been established $[6,9]$. We found a lack of adequate basic data about oesophageal carcinoid even in reference books such as Robbins and Cotran Pathologic Basis of Disease [10] or Odze \& Goldblum Surgical Pathology of the GI Tract, Liver, Biliary Tract, and Pancreas [11].

\section{Aim}

Based on this vague and incomplete information, we aimed to collect information on oesophageal carci- 
noid tumours in a systematic review study. We used the term carcinoid for typical carcinoid tumours or well-differentiated neuroendocrine tumours.

\section{Material and methods \\ Search strategies}

Three databases (PubMed, Scopus, and Web of Science) were searched for the characteristics of carcinoid tumour of oesophagus using the term "carcinoid" combined with "oesophageal" for publications with English abstracts.

\section{Study selection}

One author (M.S) searched the studies, and then a second author (M.R) who was blinded to the first author. The disagreement between two authors was resolved with a two-way conversation. Studies included: 1) original articles, case series, or case reports; 2) reporting at least one of the characteristics of benign carcinoid tumour or carcinoid tumour.

\section{Data extraction}

Name of first author, year of publication, number of patients, age, sex, tumour size, tumour behaviour, signs and symptoms; tumour site, and additional findings were extracted for every study.

\section{Results}

Out of 670 studies searched, 18 studies were assessed for eligibility. Four studies were excluded, and therefore 14 studies $[4,6,7,9,12-21]$ were included and analysed in the systematic review (Figure 1).

Fourteen studies from 1968 to 2016 included 19 patients with carcinoid tumour; 11 (57.9\%) patients were male and 8 (42.1\%) patients were female (Table I). The mean age at diagnosis was 55.5 years (range: $26-$ 82 years). The mean tumour size was $2.44 \mathrm{~cm}$ (range: $0.3-12 \mathrm{~cm}$ ). Out of nine studies reporting behaviour of the tumour, six studies (66.7\%) had non-aggressive behaviour. Out of 11 studies reporting signs of tumour, six $(54.5 \%)$, four $(36.4 \%)$, three $(27.3 \%)$, one $(9 \%)$, one (9\%), one (9\%), and one (9\%) cases had a history of dysphagia, weight loss, heartburn, lassitude and fatigue, gastrointestinal bleeding, epigastric soreness, and no symptoms, respectively. Out of 15 cases reporting the tumor site, the lower oesophagus was in 12 (80\%), the upper oesophagus in 2 (13.3\%), and the middle oesophagus in one (6.7\%).

\section{Discussion}

This study reported a number of characteristics of oesophageal carcinoid that were ambiguous in reference books and sources. A review in early 2017 included a total of 1574 oesophageal cancers; 14 (0.89\%) were cases of neuroendocrine neoplasm and 1/14 (7.1\%) had oesophageal carcinoid [2]. Hoang et al. [6] included 13 patients who were diagnosed as upper gastrointestinal carcinoid tumours, of which just 1 (7.7\%) patient had oesophageal carcinoid, and in another study this figure was $7.9 \%$ [22].

Lindberg et al. [3] concluded that most NET patients are male, mainly in the sixth to seventh decade of life. Neuroendocrine tumours of the oesophagus are typically located in the distal half of the organ. They show no special hormonal syndrome, but present with clinical features that are also common to the other types of oesophageal cancer, i.e. dysphagia, severe weight loss, and sometimes chest pain [1]. The NET tumours are usually of large size $(>4 \mathrm{~cm})$ [3].

Studies reported before 1990 showed that oesophageal carcinoid usually occurs in the lower oesophagus, with a male-to-female ratio of $6: 1[23,24]$, who presented most commonly with dysphagia, weight loss, pain, reflux esophagitis, fatigue, and melanotic stools. This study reported that the age at diagnosis of oesophageal carcinoid ranged from 30 to 82 years [23]. Lesions of oesophageal carcinoids are typically large, polypoid, and confined to the submucosa or lamina propria [25]. In one of the reference books [11] it was mentioned

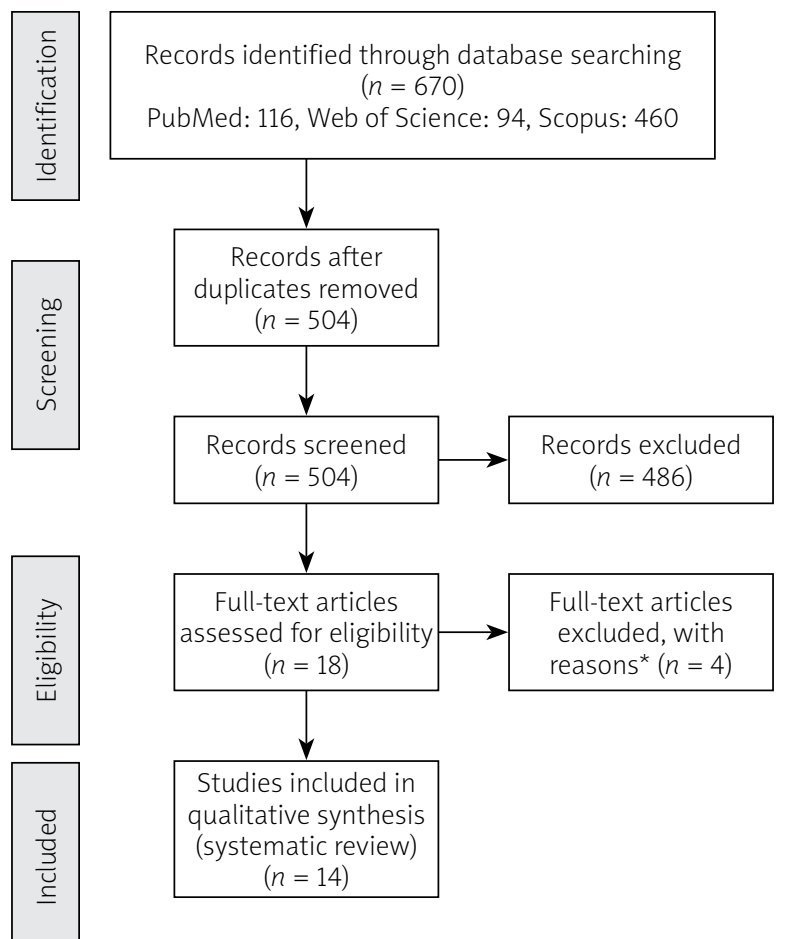

Figure 1. Flowchart of the systematic review study

*4 studies were review. 
Table I. Characteristics of the studies included in the review $(n=14)$

\begin{tabular}{|c|c|c|c|c|c|c|c|c|}
\hline $\begin{array}{l}\text { First } \\
\text { author, } \\
\text { year }\end{array}$ & $\begin{array}{l}\text { Number of } \\
\text { patients }\end{array}$ & Age & Sex & $\begin{array}{l}\text { Size of } \\
\text { tumour } \\
{[\mathrm{cm}]}\end{array}$ & $\begin{array}{l}\text { Behavior } \\
\text { of tumour }\end{array}$ & $\begin{array}{l}\text { Additional } \\
\text { findings }\end{array}$ & Signs and symptoms & Tumour site \\
\hline $\begin{array}{l}\text { Brodman, } \\
1968\end{array}$ & 1 & 66 & $\mathrm{~F}$ & - & Aggressive & - & - & Lower \\
\hline $\begin{array}{l}\text { Brenner, } \\
1969 \text { [7] }\end{array}$ & 1 & 56 & M & - & Aggressive & - & $\begin{array}{l}\text { 17-week history of severe } \\
\text { dysphagia and weight loss }\end{array}$ & Lower \\
\hline $\begin{array}{l}\text { Chong, } \\
1979[12]\end{array}$ & 1 & 55 & $M$ & 2 & - & $\begin{array}{l}\text { Mucin-producing } \\
\text { adenocarcinoma }\end{array}$ & 1-month history of dysphagia & Upper \\
\hline $\begin{array}{l}\text { Rankin, } \\
1980[13]\end{array}$ & 1 & 54 & M & 12 & - & - & $\begin{array}{c}\text { 4-month history of progressive } \\
\text { dysphagia and 14-lb weight } \\
\text { loss }\end{array}$ & Lower \\
\hline $\begin{array}{l}\text { Cary, } \\
1993[14]\end{array}$ & 1 & 57 & $M$ & - & - & Adenocarcinoma & $\begin{array}{l}\text { 20-year history of heartburn } \\
\text { with a 3-month history of } \\
\text { lassitude and fatigue }\end{array}$ & Lower \\
\hline $\begin{array}{l}\text { Partensky, } \\
1993[15]\end{array}$ & 1 & 64 & $M$ & 4 & $\begin{array}{l}\text { Non- } \\
\text { aggressive }\end{array}$ & - & $\begin{array}{c}\text { Dyspepsia and episodic } \\
\text { dysphagia }\end{array}$ & Lower \\
\hline $\begin{array}{l}\text { Hauser, } \\
1995[16]\end{array}$ & 3 & Mean: 48 & $\mathrm{~F}$ & - & - & - & - & - \\
\hline $\begin{array}{l}\text { Tanida, } \\
1998[17]\end{array}$ & 1 & 63 & M & 1.1 & - & - & - & Lower \\
\hline $\begin{array}{l}\text { Hoang, } \\
2002[6]\end{array}$ & 4 & $\begin{array}{l}\text { Mean: } \\
63 \text { (range: } \\
48-82 \text { ) }\end{array}$ & $\begin{array}{l}M: 3 \\
F: 1\end{array}$ & $\begin{array}{l}\text { Mean: } 1.5 \\
\text { (range: } \\
0.3-3.5 \text { ) }\end{array}$ & $\begin{array}{l}\text { Non- } \\
\text { aggressive }\end{array}$ & $\begin{array}{l}\text { Adenocarcinoma: } \\
2\end{array}$ & $\begin{array}{l}\text { Dysphagia and weight loss - } \\
\text { dysphagia and heartburn }\end{array}$ & $\begin{array}{c}\text { Lower: } 2 \\
\text { Middle: } 1 \\
\text { Unknown: } 1\end{array}$ \\
\hline $\begin{array}{l}\text { Chuah, } \\
2005[4]\end{array}$ & 1 & 26 & M & 0.7 & $\begin{array}{l}\text { Non- } \\
\text { aggressive }\end{array}$ & - & Gastrointestinal bleeding & Lower \\
\hline $\begin{array}{l}\text { Kreuseler, } \\
2010[18]\end{array}$ & 1 & 77 & $\mathrm{~F}$ & 1.5 & $\begin{array}{l}\text { Non- } \\
\text { aggressive }\end{array}$ & - & $\begin{array}{l}\text { 2-month history of dysphagia } \\
\text { and consecutive weight loss }\end{array}$ & Upper \\
\hline $\begin{array}{l}\operatorname{Lim}, \\
2013[19]\end{array}$ & 1 & 49 & $\mathrm{~F}$ & 0.8 & $\begin{array}{l}\text { Non- } \\
\text { aggressive }\end{array}$ & - & $\begin{array}{l}\text { Intermittent epigastric } \\
\text { soreness and heartburn }\end{array}$ & Lower \\
\hline $\begin{array}{l}\text { Yagi, } \\
2015[20]\end{array}$ & 1 & 43 & $\mathrm{~F}$ & 0.3 & $\begin{array}{l}\text { Non- } \\
\text { aggressive }\end{array}$ & - & - & Lower \\
\hline $\begin{array}{l}\text { Kim, } \\
2016 \text { [9] }\end{array}$ & 1 & 56 & M & 0.5 & $\begin{array}{c}\text { Non- } \\
\text { aggressive }\end{array}$ & - & - & Lower \\
\hline
\end{tabular}

that carcinoid tumours are uncommon in the oesophagus, and these cases showed a male predominance, and most of them were distal, particularly at the gastroesophageal junction. Fifty per cent of them were metastatic at the time of diagnosis.

This disease is very rare, and therefore the number of reported patients is low in the present study. In the literature the definition of carcinoid in the studies was different.

\section{Conclusions}

This meta-analysis showed that the mean age at diagnosis was 55.5 years (range: $26-82$ years). The tumour was around 1.4 times more prevalent in males and located mainly in the distal (lower) oesophagus. The mean tumour size was $2.4 \mathrm{~cm}$ (range: $0.3-12 \mathrm{~cm}$ ) and the most tumours were non-secretor. The main symptoms of this disease were dysphagia, weight loss, and reflux. The tumour behaviour was mainly non-aggressive except for cases associated with adenocarcinoma.

\section{Conflict of interest}

The authors declare no conflict of interest.

\section{References}

1. Klöppel G, Anlauf M. Epidemiology, tumour biology and histopathological classification of neuroendocrine tumours of the gastrointestinal tract. Best Pract Res Clin Gastroenterol 2005; 19: 507-17.

2. Tustumi F, Takeda FR, Uema RH, et al. Primary neuroendocrine neoplasm of the oesophagus - report of 14 cases from a single institute and review of the literature. Arq Gastroenterol 2017; 54: 4-10. 
3. Lindberg GM, Molberg KH, Vuitch MF, et al. Atypical carcinoid of the oesophagus. A case report and review of the literature. Cancer 1997; 79: 1476-81.

4. Chuah SK, Hu TH, Kuo CM, et al. Upper gastrointestinal carcinoid tumours incidentally found by endoscopic examinations. World J Gastroenterol 2005; 11: 7028-32.

5. Modlin IM, Sandor A. An analysis of 8305 cases of carcinoid tumours. Cancer 1997; 79: 813-29.

6. Hoang MP, Hobbs CM, Sobin LH, et al. Carcinoid tumour of the oesophagus: a clinicopathologic study of four cases. Am J Surg Pathol 2002; 26: 517-22.

7. Brenner S, Heinlich H, Widman M. Carcinoid of oesophagus. New York J Med 1969; 69: 1337-9.

8. Kos-Kudła B. Treatment of neuroendocrine tumours: new recommendations based on the CLARINET study. Contemp Oncol (Pozn) 2015; 19: 345-349.

9. Kim NR, Kim YJ, Hwang IC. A carcinoid tumor of the esophagus treated with endoscopic ablation therapy. J Nepal Med Assoc 2016; 55: 97-9.

10. Robbins and Cotran Pathologic Basis of Disease. $9^{\text {th }}$ ed. Kumar V, Abbas AK, Aster JC (eds.). Elsevier Saunders, Philadelphia 2015; 774.

11. Odze RD, Goldblum JR. Surgical Pathology of the GI Tract, Liver, Biliary Tract and Pancreas. $3^{\text {rd }}$ ed. Elsevier Saunders, Philadelphia 2015; 813-4.

12. Chong FK, Graham JH, Madoff IM. Mucin-producing carcinoid ("composite tumour") of upper third of oesophagus: a variant of carcinoid tumour. Cancer 1979; 44: 1853-9.

13. Rankin R, Nirodi NS, Browne MK. Carcinoid tumour of the oesophagus: report of a case. Scott Med J 1980; 25: 245-9.

14. Cary NR, Barron DJ, McGoldrick JP, et al. Combined oesophageal adenocarcinoma and carcinoid in Barrett's oesophagitis: potential role of enterochromaffin-like cells in oesophageal malignancy. Thorax 1993; 48: 404-5.

15. Partensky C, Chayvialle JA, Berger F, et al. Five-year survival after transhiatal resection of oesophageal carcinoid tumour with a lymph node metastasis. Cancer 1993; 72: 2320-2.

16. Hauser $\mathrm{H}$, Wolf $\mathrm{G}$, Uranüs $\mathrm{S}$, et al. Neuroendocrine tumours in various organ systems in a ten-year period. Eur J Surg Oncol 1995; 21: 297-300.

17. Tanida S, Miyamoto T, Katagiri K, et al. Carcinoid of the oesophagus located in lamina propria. J Gastroenterol 1998; 33: 541-5.

18. Kreuseler T, Stolte M, Adamek RJ. Neuroendocrine tumour of the oesophagus - successful endoscopic treatment of a very rare entity. Dtsch Med Wochenschr 2010; 135: 19-21.

19. Lim CS, Park SJ, Park MI, et al. Successful endoscopic mucosal resection of a low oesophageal carcinoid tumour. Clin Endosc 2013; 46: 576-8

20. Yagi M, Abe Y, Sasaki Y, et al. Esophageal carcinoid tumour treated by endoscopic resection. Dig Endosc 2015; 27: 527-30.

21. Estrozi B, Bacchi CE. Neuroendocrine tumours involving the gastroenteropancreatic tract: a clinicopathological evaluation of 773 cases. Clinics (Sao Paulo) 2011; 66: 1671-5.

22. Broicher K, Hienz HA. Karzinoid-Syndrom bei im Osophagus lokalisiertem Primartumor. Z Gastroenterol 1974; 12: 377-84.

23. Griffin M, Sweeney EC. The relationship of endocrine cells, dysplasia and carcinoembryonic antigen in Barrett's mucosa to adenocarcinoma of the oesophagus. Histopathology 1987; 11: 53-62.

24. Ready AR, Soul JO, Newman J, et al. Malignant carcinoid tumour of the oesophagus. Thorax 1989; 44: 594-6.

25. Adsay NV, Klimstra DS. Neuroendocrine tumors of the gastrointestinal and pancreatobiliary tracts. In: Surgical Pathology of GI Tract, Liver, Biliary Tract and Pancreas. $3^{\text {rd }}$ ed. Odze RD, Goldblum JR (eds). Elsevier; Philadelphia, PA, USA 2015; 803-20.11.

Received: 25.08 .2017

Accepted: 4.01 .2018 